\title{
A geophysical and hydro physico-chemical study of the contaminant impact of a solid waste landfill (swl) in King Williams' Town, Eastern Cape, South Africa
}

https://doi.org/10.1515/geo-2019-0045

Received September 6, 2018; accepted May 29, 2019

\section{Introduction}

In the South African context, waste is any undesirable or superfluous by- product of emissions or residue of any process or activity which has been discarded, normally accumulated or stored for the purpose of discarding or further processing through treatment (1). Waste disposal dumps are common phenomena especially in industrial and highly populated cities where dumps are generated in tons on a daily basis and thus becomes a more important and efficient way of maintaining a clean environment in urban settings. In developing countries unregulated landfills are commonly located adjacent to large cities, releasing harmful contaminants into a leachate and thereby polluting underlying aquifers (2).

Municipal solid waste landfills/dumpsites have been identified as major environmental problem when located at high proximity to inhabited areas (3). In most cases, dumpsites were originally located far from urban areas. But increasing expansion due to ever- increasing population and urbanization have resulted in development of land adjacent to dumps as either public buildings or residential houses. Therefore, humans are exposed to a range of environmental hazards but particularly percolation of polluted leachate into the shallow aquifers, which is the main source of drinking water in developing countries and in most cases, disposal sites are not properly planned. Thus, periodical environmental auditing exercises become an inevitable task to ascertain the conditions of waste site with view to gain the knowledge of possible interaction between its dumps and the environment. The environmental challenges of waste dumps include contamination of groundwater by pollutants generated by the dumps, migration of the pollutants away from the site via groundwater, surface water, or air routes, a combination of these, fire and explosion at the site, and direct contact with hazardous substances (4). The most common approach for investigating leachate plume migra-

\footnotetext{
*Corresponding Author: S. Mepaiyeda: Department of Geology, University of Fort Hare, Private Bag X1314, Alice 5700, South Africa, E-mail: 201714260@ufh.ac.za

K. Madi, O. Gwavava: Department of Geology, University of Fort Hare, Private Bag X1314, Alice 5700, South Africa

C. Baiyegunhi: Department of Geology, University of Fort Hare, Private Bag X1314, Alice 5700, South Africa

Department of Geology and Mining, University of Limpopo, Private Bag X1106, Sovenga 0727, South Africa
} 
tion from a dumpsite is to drill a network of monitoring wells around the site. However, these wells are expensive to construct and maintain (5). In addition, limited information on subsurface hydrogeology and/ or budget limitations frequently compels the citing of monitoring wells at random. This approach is both technically and economically inefficient because "monitoring wells give point measurements, whereas leachate plumes tend to migrate along preferential pathways, determined by subsurface heterogeneity" (5). Therefore, even with a network of closely spaced monitoring wells, the risk that some contaminants could go undetected remains high. For these reasons, there is widespread interest in applying non-invasive and relatively inexpensive geophysical techniques, such as electrical resistivity imaging (ERI), electromagnetic methods, EC logging, and seismic surveys, as means for mapping the occurrence and movement of leachate and for facilitating decision making regarding the location of monitoring wells (6),(7). In this study, we used electrical geophysical method involving electrical resistivity imaging and 2D profiling (Dipole - Dipole) techniques to map possible leachate distribution and migration processes from the landfill site in King Williams Town, Eastern Cape Province of South Africa. The two techniques are based on the response of underground geologic features to a current flow field and are capable of detecting different subsurface units on the basis of the contrasts in electrical resistivity of earth materials. They are fast and cost effective. The former measures the vertical variations in resistivity of the subsurface earth while the latter involves the measurement of lateral and vertical variations of the apparent resistivity of the subsurface earth. The integrated use of geophysical and hydro physiochemical methods are often recommended in landfill studies (8), (9), and (10). The specific objectives of this study is to delineate groundwater contamination, identify lithological layers, locate possible leachate plumes, and assess the risk of groundwater pollution as a result of the dumpsite. This is with the view of assessing the risk associated with the groundwater abstraction in the area. The outcomes of this study will help appropriate decision-making on how and where to abstract underground water and remediation methods to adopt.

The Eastern Cape Province (Figure 1) lies on the south-eastern seaboard of South Africa. It is the second largest province with an area extent of approximately $169580 \mathrm{~km}^{2}$, representing $13.9 \%$ of South Africa's total landmass (11). Despite the existence of a range of alternative disposal technologies, waste management services in the Eastern Cape Province rely heavily on landfills for the disposal of waste, which account for the majority of licensed waste facilities (12). Waste disposal facilities like landfill sites, waste storage facilities, recycling facilities, materials recovery facilities and waste transfer facilities are crucial indicators in determining where municipal solid waste material ends up.

Based on the findings of the investigation carried out by DEAT (2001), it was revealed that there are 101 operational waste disposal sites in the Eastern Cape Province, 74 sites reported from questionnaires, 7 sites from permitting records and 20 sites estimated by projection. It is estimated that only $8 \%$ of landfills in the Eastern Cape Province complied with DWAF minimum requirements, $54 \%$ could potentially comply and $38 \%$ are currently unacceptable (13).

The Buffalo City Metropolitan Municipality, which is the catchment area of this research owns and operates two licensed landfill sites, namely, King Williams Town dumpsite and Round Hill dumpsite which is situated $4 \mathrm{~km}$ east of Berlin. The landfill site in King Williams Town is located around West Bank Primary School between longitudes $27.394-29.3915^{\circ} \mathrm{E}$ and latitudes $-32.8525-32.8495^{\circ} \mathrm{S}$, covering an area of about $0.30 \mathrm{~km}^{2}$ (Figure 2a-d). The landfill is an abandoned quarry in which landfilling started in 1983 by open dumping. The land fill receives a mixture of municipal, commercial, and mixed industrial wastes with hazardous and non-hazardous constituents. These often go into the landfill unsorted and releases large amount of gases, particles and leachates into the surrounding soil and ground water.

Water containing dissolved contaminants form the landfill is collected and contained in the leachate pond. There are two groundwater monitoring boreholes $\mathrm{BH} 1$ and BH2 located south and southeast of the site, respectively (Figure 3). The landfill site is characterised by steep topography with the direction of dip in the northeast- southwest direction.

\section{Geology}

The study area is geologically setting within the Beaufort group, Karoo Supergroup which is the dominant stratigraphic sequence in the Eastern Cape, South Africa. Most of the continental deposits of the Karoo Supergroup are grouped in the aerially broad Beaufort Group that developed from a large quantity of the sediments, produced from the fast rising Cape Fold Belt (14). The Karoo Basin fill that is seen along the Eastern Cape Province of South Africa started with the deposition of the glacial sediments of the Dwyka Group with a thickness of approximately $600 \mathrm{~m}-700 \mathrm{~m}$ (15). This formation is overlain by the postglacial Ecca Group, followed by the Beaufort and Storm- 


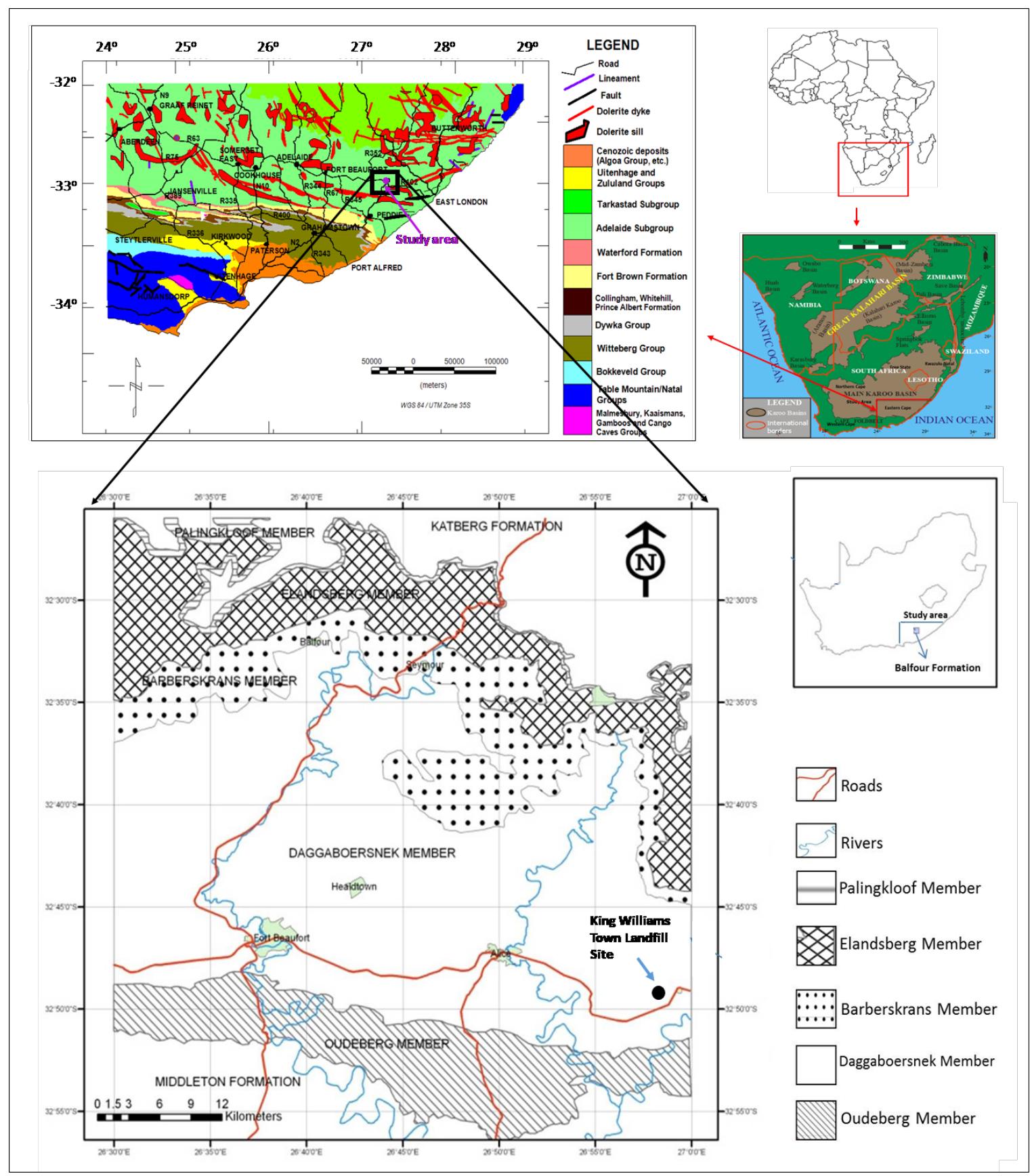

Figure 1: Map showing the study area and the distribution of sediments of the Oudeberg, Daggaboersnek, Barberskrans, Elandsberg, and Palingkloof Members of the Balfour Formation (Modified after Katemaunzanga and Gunter, 2009; Baiyegunhi et al., 2016).

berg Groups (15). The whole sequence of deposition is covered by the basalt and pyroclastic deposits of the Drakensberg Group (Table 1). The study area falls in the Beaufort Group, so the geology will focus more on the Beaufort Group.

The Beaufort Group consists of fine-grained sandstones and mudstones that show fining-upward sequence (16). The group consists of the Adelaide and Tarkastad Subgroups (14) (17). Generally, the Adelaide Subgroup reaches a maximum thickness of about $5,000 \mathrm{~m}$ in the southeastern part and consists of a succession of bluishgrey, reddish-maroon and greenish-grey mudstones and subordinate fine-to medium-grained, tabular and lenticular sandstone. Though, the thickness decreases to about $800 \mathrm{~m}$ in the centre of the Main Karoo Basin. Subsequently, the thickness gradually decreases to around $100-200 \mathrm{~m}$ in the far north of the basin (17). Furthermore, the Adelaide Subgroup that forms the lower part of the group comprises 


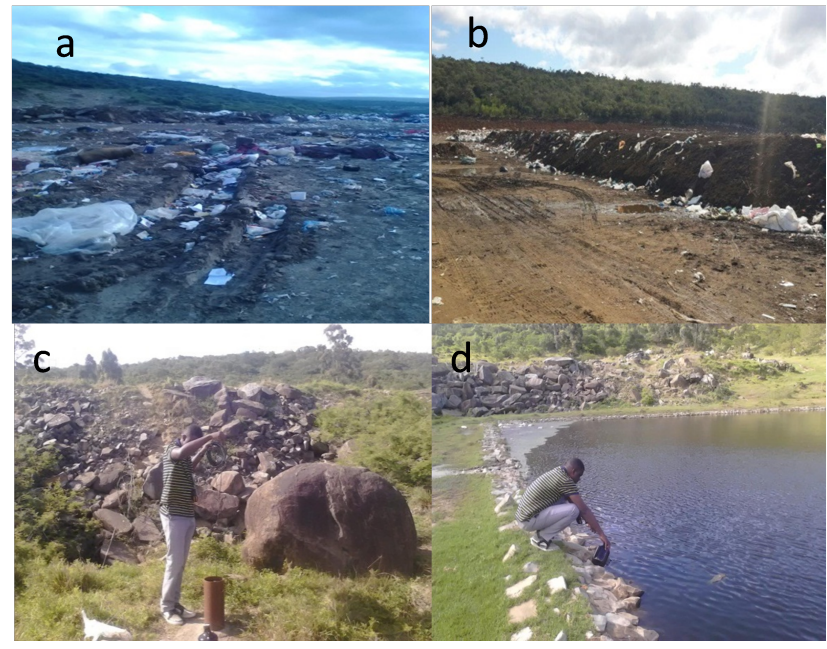

Figure 2: (a) Dumpsite surface composition viewed from the South; (b) Dumpsite surface composition viewed from the East; (c) Groundwater monitoring borehole located south of the landfill; (d) Leachate pond located south-west of the landfill.

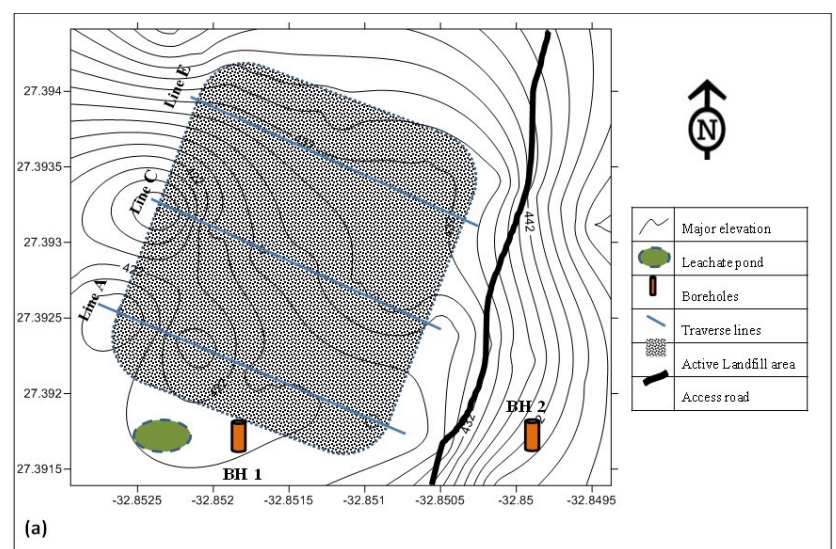

(a)

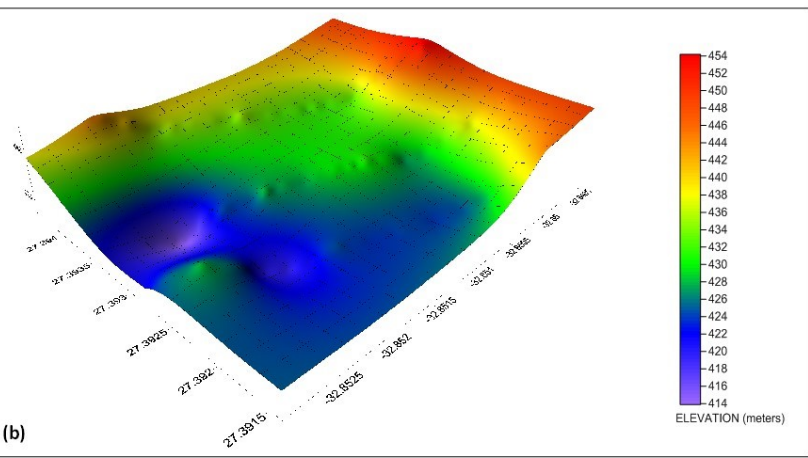

Figure 3: (a) Map of the landfill area showing profile lines, borehole and contoured elevation. (b) 3-D surface map of the landfill site.

of three formations, namely; Koonap, Middleton and Balfour Formations. The Koonap Formation consists of greenish silty-mudstones and sandstones in a fining upward sequence deposited when a high energy braided river system graded into a lower energy meandering river system (18).
The Middleton Formation has dark red and greenish grey mudstones interbedded with sandstones in an overall fining upward sequence.

The Balfour Formation is a fining upward sequence of greenish-grey sandstones with bands of darker mudstones. The formation is thought to have been deposited when braided rivers graded upwards into meandering stream systems (18). The Oudeberg, Daggaboersnek, Barberskrans, Elandsberg, and Palingkloof Members are the five members that make up the Balfour Formation (Figure 1). These members are distinguished based on the lithological variation, which is characterised by the alternating sequence of sandstones and mudstones. The distribution of sediments of the five members that make up the Balfour Formation is shown in Figure 1.

The study area is geologically within the Daggaboersnek Member of the Balfour Formation in the Beaufort Group, Karoo Supergroup, which is the dominant stratigraphic sequence in the Eastern Cape of South Africa.The local geology of the landfill site consists of superficial deposits of alluvium, siltstone, mudstone and sandstone. The Balfour Formation sediments have been extensively intruded and baked by dolerite sills in the Early Jurassic (19). The bedrock formation is made up of dolerite sills, which are more pronounced at the southern parts of the landfill site. The lithological formations of the landfill site are characterised by low porosity and permeability, consequently affecting the hydraulic properties of aquifers around the landfill site.

\section{Materials and Methods}

The electrical resistivity method and physico-chemical analysis of water samples from the leachate pond and boreholes within the vicinity of the landfill were carried out to investigate possible contamination to groundwater by leachate from the dumpsite. Two dimensional

(2-D) was carried out using a multi-channel resistivity meter (SYSCAL -PRO). Three parallel profiles (A, C and E) were ran at inter - profile spacing of $100 \mathrm{~m}$ and a profile length of $360 \mathrm{~m}$ in the east - west direction (Figure 3).

There is an access road about $10 \mathrm{~m}$ wide on the eastern flank of the site which runs in a north - south direction. Measurements were made at increasing offset distance (aspacing) of $10 \mathrm{~m}$ which also runs over the access road in order to image the subsurface around the immediate vicinity of the landfill site.

The measurement protocol is computer controlled using a laptop microcomputer together with an electronic 
Table 1: Lithostratigraphy of the Karoo Supergroup in the Eastern Cape Province compiled by the Council for Geoscience (Johnson et al., 2006).

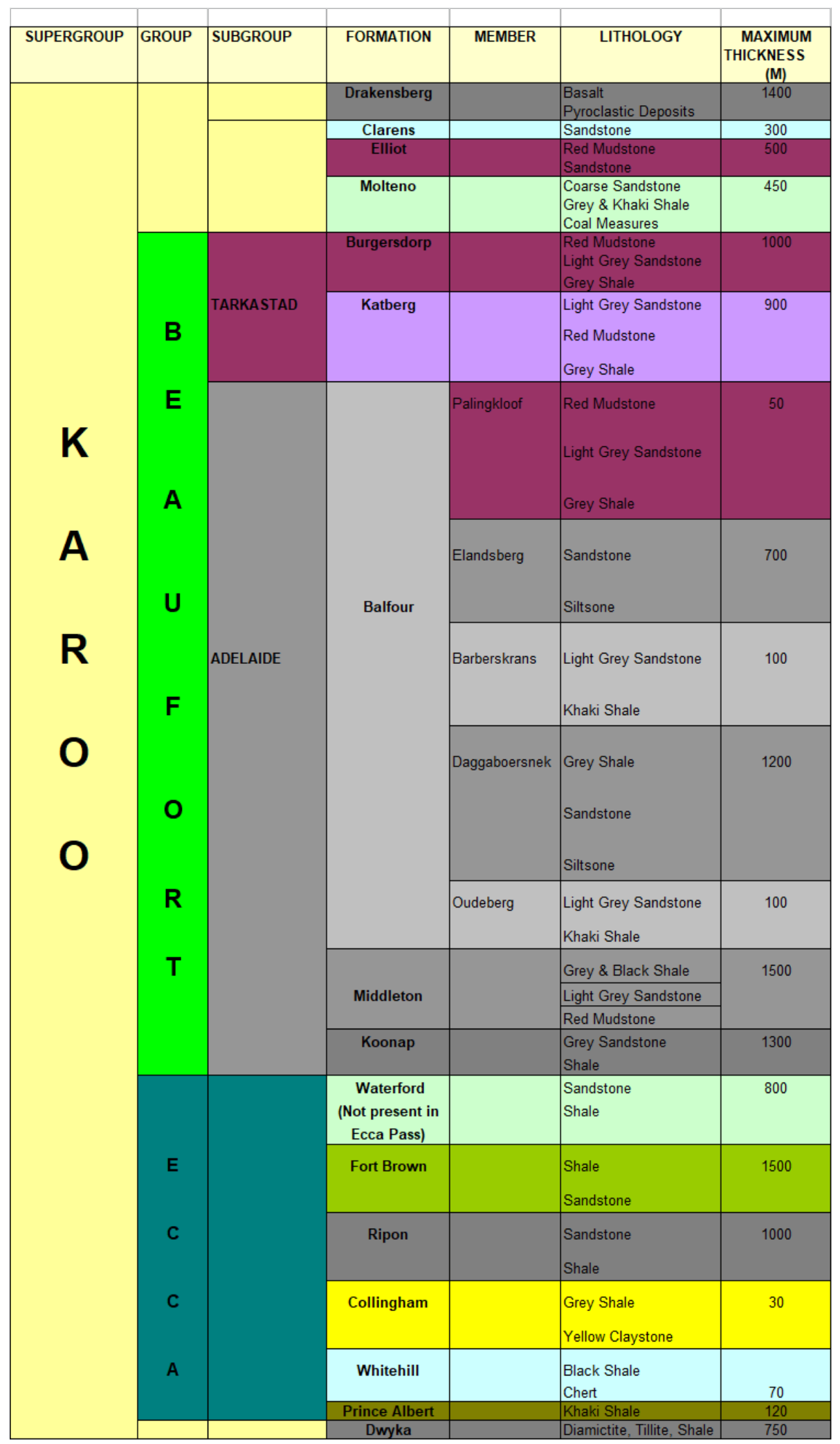


switching unit used to automatically select the relevant four electrodes for each measurement. Selection of minimum electrode spacing was based on the target (leachate). Dipole-dipole electrode configuration was chosen for its relative sensitivity to vertical changes in the sub- surface resistivity below the centre of the array and for its ability to resolve vertical changes (i.e. horizontal structures) (20). The measured $2-D$ resistivity data were processed using RES2DINV inversion software (21). The program uses the least - squares inversion scheme to minimize the difference between the calculated and measured apparent resistivity values, by iterative process. The results are displayed as inverted sections of the true resistivity of the subsurface rocks (Figures $4 \mathrm{a}-\mathrm{c}$ ). The sections were subsequently, visually inspected to delineate areas of anomalously high or low resistivities related to subsurface structures.

In-situ data which reflects the physico-chemical properties of the water samples were also taken. The leachate pond is about $80 \mathrm{~m}$ from the edge of the landfill while the two boreholes $\mathrm{BH} 1$ and $\mathrm{BH} 2$ are at a range of $130-200 \mathrm{~m}$ from the landfill respectively. Parameters of the water samples such as temperature, $\mathrm{pH}, \mathrm{EC}$, TDS, salinity and turbidity were measured using the PHARO-100 spectrophotometer. This is a device that measures chemical or physical properties of samples by influencing a substrate to determine the presence of possible contamination and the degree. The degree of contamination will be determined by juxtaposing the results obtained with threshold values which are usually World Health Organization (WHO) standards.

Topographic profiles of the resistivity imaging lines were made by measuring point elevations and coordinates at regular intervals $(10 \mathrm{~m})$ along the profile lines. Data points from these measurement were then modelled using the inversion software to obtain topographic profiles along each line. The depth of penetration along the lines ranges from $70 \mathrm{~m}-80 \mathrm{~m}$

\section{Results}

\section{2-D Resistivity Imaging}

The resistivity distribution derived from the 2-D inversion in the west - east direction is given in Figures $4 \mathrm{a}-\mathrm{c}$ below;

Electrical Resistivity Imaging (ERI) Interpretation;

Schlumberger resistivity data were modelled to generate geoelectric sections along the profile lines as shown below;

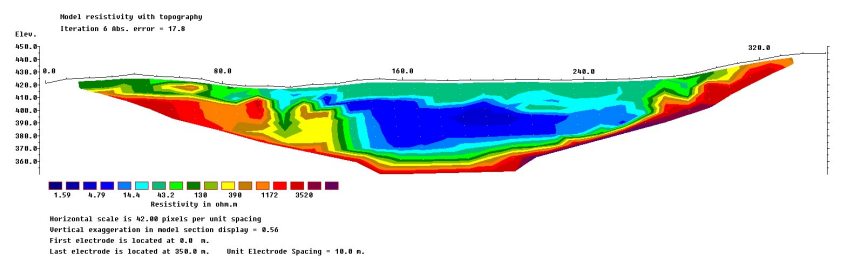

(a)

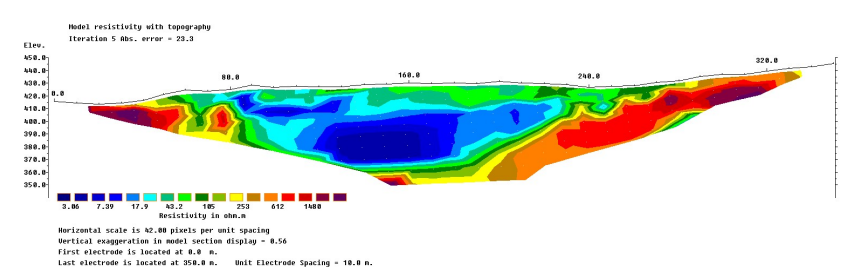

(b)

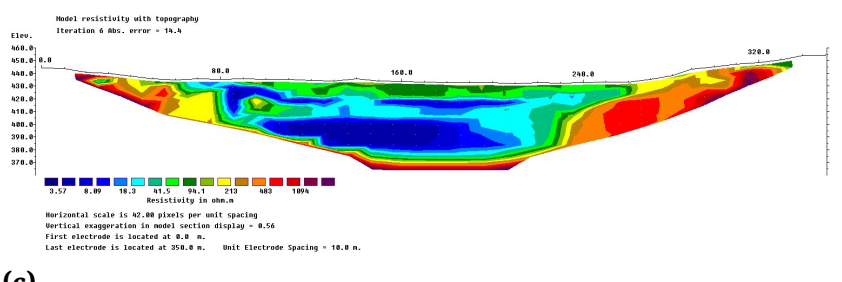

(c)

Figure 4: (a) Dipole-dipole resistivity data along Line A, (b) Dipoledipole resistivity data along Line $C$, (c) Dipole-dipole resistivity data along Line $\mathrm{E}$

Figures 5a- c showed a 4-layer geoelectric section with varying thicknesses and resistivity across the profile lines.

Hydro-physicochemical analysis;

Many authors have noted that, besides the vertical infiltration of leachate from the solid waste, the hydrological groundwater flow also play a prominent role in contaminant distributions beneath the subsurface of a landfill or dumpsite, (22) (23). This accounts for the contamination of groundwater aquifer not directly or vertically located on dumpsites or landfills across the globe.

Water samples from the leachate pond (LP), having an area of about $20 \mathrm{~m}^{2}$, located south-west of the landfill and two boreholes (BH1) and (BH 2), located at the south and south-west of the landfill with depths to the top of the water column of $2.5 \mathrm{~m}$ and $1.5 \mathrm{~m}$ respectively were collected and analysed on the site for their physico-chemical properties using the PHARO-100 spectrophotometer. The obtained results were then compared with world health organization (WHO) standards (24), to determine the degree of contamination of the water samples. The summary of the results are given below; 


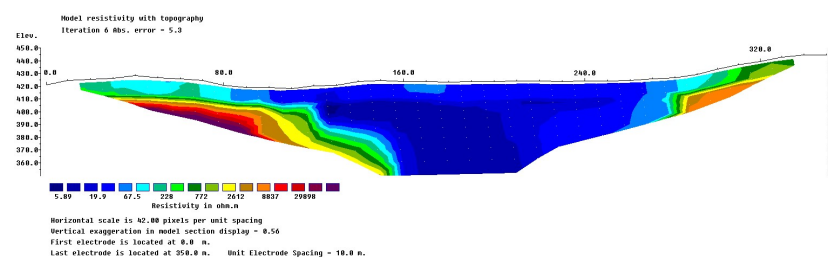

(a)

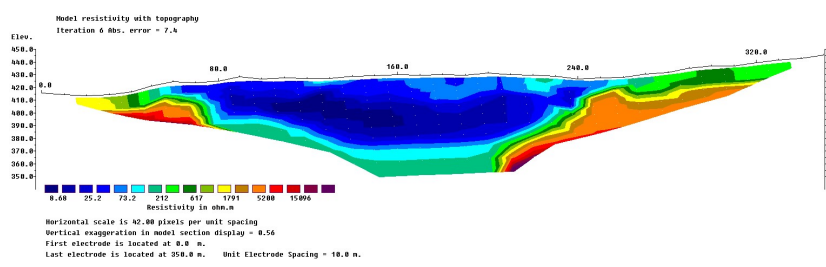

(b)

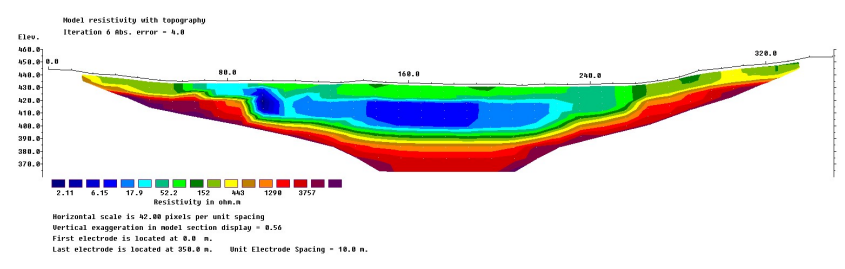

(c)

Figure 5: (a) Schlumberger array resistivity data along Line A, (b) Schlumberger array resistivity data along Line C, (c) Schlumberger array resistivity data along Line $\mathrm{E}$

Table 2: Physico-chemical properties of water samples from the landfill site.

\begin{tabular}{|c|c|c|c|c|}
\hline PARAMETER & BH2 & LP & BH1 & $\begin{array}{l}\text { WHO } \\
\text { Standards }\end{array}$ \\
\hline Ph voltage (mVpH) & \begin{tabular}{|l|}
-34.6 \\
\end{tabular} & \begin{tabular}{|l|}
-79.7 \\
\end{tabular} & \begin{tabular}{|l|}
-69.4 \\
\end{tabular} & . \\
\hline $\mathrm{pH}(\mathrm{pH})$ & 6.87 & 7.65 & 7.47 & $6.5-8.5$ \\
\hline $\begin{array}{l}\text { Oxidation-Reduction Potential } \\
\text { (mVORP) }\end{array}$ & 104.1 & 58.7 & 73.1 & $0--400$ \\
\hline $\begin{array}{l}\text { Electrical conductivity } \\
\qquad \mathrm{EC}(\mu \mathrm{S} / \mathrm{cm})\end{array}$ & 6988 & 6580 & 9892 & $500-5000$ \\
\hline$\left(\mu \mathrm{S} / \mathrm{m}^{\mathrm{A}}\right)$ & 70.36 & 66.49 & 99.84 & $5 \cdot 50$ \\
\hline Molar conductivity $(\mathrm{m} \Omega \cdot \mathrm{cm})$ & 0.0001 & 0.0002 & 0.0001 & - \\
\hline Total dissolved solids (TDS) (mg/L) & 3497 & 3298 & 4939 & 500 \\
\hline Salinity (PSU) & 3.83 & 3.60 & 5.55 & $2-42$ \\
\hline Surface tension $(\sigma t)$ & 0.0 & 0.0 & 1.1 & \\
\hline Temperature $\left({ }^{\circ} \mathrm{C}\right)$ & 25.35 & 25.45 & 25.50 & 25 \\
\hline Pressure (psi) & 13.758 & 13.758 & 13.758 & \\
\hline Dissolved oxygen (DO) (mg/L) & 0.91 & 0.63 & 7.24 & \\
\hline Turbidity (NTU) & \begin{tabular}{|l|l|}
19.4 \\
\end{tabular} & 2.46 & 1.46 & \\
\hline
\end{tabular}

\section{Discussion}

Profile A lies at about $30 \mathrm{~m}$ from the south edge of the landfill and point elevation of $420 \mathrm{~m}$. The low resistivity zones with resistivity between $1.59-14.4 \Omega \mathrm{m}$ (deep blue) occur at surface points between $120-230 \mathrm{~m}$, around the mid-point of the section.

This low resistivity value shows an infiltration of leachate into the subsurface to a depth of about $47 \mathrm{~m}$. This is interpreted to be mudstones and sandstones saturated with leachate. The high resistivity zones (brown to purple) with resistivity values between $1172-3520 \Omega \mathrm{m}$ at the flanks of the section indicates non-conductive, impermeable layer formed by part of the road sub-base to the east and doleritic bedrock to the west. Sandwiched between these zones of low and high resistivity anomaly is an intermediate zone (light green to yellow), showing rock materials having varying moisture content and composition.

Profile C is located at about $100 \mathrm{~m}$ from profile A around the centre of the landfill site at point elevation of about $415 \mathrm{~m}$. The low resistivity zones $(<7.39 \Omega \mathrm{m})$ are more pronounced on this profile. The most dominant of this low resistivity anomaly occurs at $30-230 \mathrm{~m}$ surface points at a depth of $75 \mathrm{~m}$ to the west of the profile. This is interpreted as mud and sandstone saturated with contaminant leachate. The shape of the leachate plume showed movement of low resistivity materials leaking towards the south-western edge of the landfill. A major reason for this is the dipping topography between line A and C. Two high resistivity anomalies were identified on this profile - a high resistivity zone at surface points $240-290 \mathrm{~m}$ and depth of $45 \mathrm{~m}$ to the east of the profile (light brown colour). This is interpreted as landfill gases, probably methane, ammonia or carbon dioxide, released by the decomposing leachate materials. The high resistivity zone to the west of the profile shows the continuation of the bedrock from line A.

Profile E lies towards the edge of the landfill at $200 \mathrm{~m}$ and $100 \mathrm{~m}$ from profiles $\mathrm{A}$ and $\mathrm{C}$ respectively. The low resistivity is less pronounced when compared with the other profiles. This is due to the higher point elevation of the profile $(450 \mathrm{~m})$. The natural soil condition is returning at this line which possibly implies escape of chemical components into the atmosphere with increased distance from the centre of the landfill. There is a reduced depth of contaminant pollution (35 m).

The composition of the lithologic layers has been considerably altered by the percolating leachate. The underlying water bearing formation is also not spared from the contamination effects (Figure 4a and 4b). 
Across line E, towards the northern edge of the landfill, contamination effects were not as pronounced as the other two profiles. This is as a result of the increasing distance from the centre of the landfill and higher point elevation as compared to the other two profiles (Figure 5c) from this profile the top layer, consisting mainly of superficial deposits has an average resistivity of $52-152 \Omega \mathrm{m}$ and thickness between $7-10 \mathrm{~m}$.The underlying mudrock has an average resistivity of $6.5-17.9 \Omega \mathrm{m}$, the low resistivity values is due to the permeating leachate plume. The average thickness of this layer is $25-30 \mathrm{~m}$. The water bearing sanstone formation underlying the mudstones has an average resistivity of $152-443 \Omega \mathrm{m}$ and thickness of about $15-20 \mathrm{~m}$. the depth to the bedrock layer is estimated to be about $85 \mathrm{~m}$.

Measurements of the physico-chemical properties of the water samples were made at an average temperature of $25^{\circ} \mathrm{c} \mathrm{pH}$. Of groundwater samples from the boreholes ranged from $6.87-7.47$ while the leachate pond has a $\mathrm{pH}$ of 7.65. These values are within the limits of the WHO standards for water. The low salinity of the water samples is as a result of the freshwater nature of their source.

However, specific conductance of the samples showed high ion concentration well above the permissible limits. This is influenced by the presence of inorganic dissolved solids such as chloride, nitrates, phosphates etc. TDS values ranged from $3497-4939 \mathrm{mg} / \mathrm{l}$ in the groundwater samples. This is above the threshold for potable water, while the leachate pond has the least TDS of $3298 \mathrm{mg} / \mathrm{l}$. A possible reason for this is due to an increase in the percolation of leachate with depth. High TDS values produce toxic effect on living organisms through high alkalinity and hardness thus causing living cells to shrink. The oxidation reduction potential which is a measure of the cleanliness of the water samples showed positive values for the three water samples collected. A direct implication of this is an increase in the oxidizing properties of the samples, thus making them unfit for consumption

\section{Conclusion}

Results of the 2-D resistivity imaging and physico- chemical analysis showed the presence of contaminants in the groundwater systems due to the landfilling. The leachate generated from the landfill has maximum impact on the groundwater quality in the locality. The soil stratigraphy being predominantly mud and sandstones has high permeability and this has significantly influenced the high level of infiltration of contaminants into the water bearing formation to a depth of $75 \mathrm{~m}$. High resistivity values encountered indicated the presence of non-conductive waste materials and the road sub-base towards the east of the profiles.

The very high EC and TDS values observed in the groundwater samples suggest a downward transfer of leachate into groundwater. The difference in EC and TDS values for $\mathrm{BH} 1$ and $\mathrm{BH} 2$ indicates that the concentration of the contaminants normally decreases with increase in distance from the centre of the pollution source.

In the absence of a leachate recovery system, the uncontrolled accumulation of leachate over time at the landfill site will pose a great risk to the groundwater quality. This will be further compounded by the steep topography of the landfill base which showed groundwater movement in the south-west direction as water moves from regions of high altitude and concentration towards the built -up areas around the landfill which are lying in the region of lower concentration and altitude.

The biological and chemical constituents of the contaminants are unknown. More detailed geochemical analysis will be required to determine their nature.

A result from this research revealed that groundwater from the study area is contaminated and also migrating steadily. This puts an emphasis on the need to improve waste management practices in the area to mitigate groundwater pollution.

Acknowledgement: The authors wish to acknowledge the following for their contributions towards the research:

- The Buffalo City Metropolitan Municipality (BCMM) for granting access permits to the landfill site

- The Council for Geosciences (CGS), South Africa, for providing instrumentation for the geophysical data acquisition

- The Applied and Environmental Microbiology Research Group (AEMREG), University of Fort Hare, South Africa for the physico-chemical analysis carried out in this research

\section{References}

[1] DEAT, 2001. Department of Environmental Affairs \& Tourism. Disposal Sites for Hazardous and general Waste in South Africa. Baseline study in preparation for the National waste management Strategy for South Africa. 2001.1st Edition, 2001

[2] McFarlane, D.S,. Cherry, J.A,. Gilham, R.W and Sudicky, E.A. “Migration of Contaminants in Groundwater at a Landfill: A Case Study". 1993 Journal of Hydrology, Vol. 63, No. 1-2, pp. 1-29. 
[3] Mor, S, Ravindra,K., Dahiya, P.R., and Chandra, A. Leachate Characterization and Assessment of Groundwater Pollution near Municipal Solid Waste Landfill Site," 2006. Environmental Monitoring and Assessment.. Vol. 118, No. 1-3, 2006, pp. 435456.

[4] Dimitriou, E., Karaouzas, I., Saratakos, I., Zacharias, I., Bogdanos, K., and Diapoulis, A. Groundwater Risk Assessment at a Heavily Industrialized Catchment and the Asso- ciated Impacts on a Peri-Urban Wetland". 2008. Journal of Environmental Management, Vol. 88, No. 3, 2008, pp538

[5] Bernstone C., Dahlin T. DC Resistivity Mapping of old landfills: Two case studies. European Journal of Environmental and Engineering Geophysics 2, 1997, pp121-136.

[6] Buselli G., Lu K., Groundwater Contamination Monitoring with Multichannel Electrical and Electromagnetic Methods. 2001, Journal of Applied Geophysics 48, pp 11-23.

[7] Butler J.J., Healey J.M, Zheng L, McCall W., and Schulmeister M.K., Hydrostratigraphic Characterization of unconsolidated alluvial deposits with direct-push Sensor Technology. 1999. Kansas Geological Survey Open-File Report, 99-40

[8] Benson, R., Olaccum, R., and Neol, M. Geophysical Techniques for Sensing Buried Waste and Waste Migration. Environmental Monitoring System Laboratory Office Research and Development. US Environmental Development Agency: 1983 Los Vegas, NV. Rep. $6803-3050$

[9] Mathias, M.S., Marques Da silver, M., Ferreira, P., and Ramalho, E. "A Geophysical and Hydrological Study of Aquifer Contamination by a Landfill”. 1994. Journal of Applied Geophysics. 32: pp155- 162

[10] Kayabali, K., Yueksel, F.A., and Veken T. "Integrated Use of Hydrochemical and Resistivity Methods in Ground Water Contamination Caused by Recently Closed Solid Waste Site". 1998. Environmental Geology. 36 ( 3 and 4):227-234

[11] Statistics South Africa. 2003. Census 2001: Census in Brief. Report No. 03-02-03

[12] SAEO: Chapter 9 - Waste Management - Draft 2.. South Africa environment outlook. 2012. Chapter 9: Waste Management Draft 218 January 2012

[13] DWAF, 1998. Department of Water Affairs and Forestry. Minimum requirements for waste disposal by Landfill. Second edition, 1998.
[14] Johnson M., van Vuuren C., Visser J., Cole D., de Wickens H., Christie A. and Roberts D.,. The Foreland Karoo Basin, South Africa., In: R. Selley (Editor). African Sedimentary Basins of the World, Elsevier, Amsterdam, vol. 3, 269-317. 1997

[15] Johnson, M.R., van Vuuren C.J., Visser, J.N.J., Cole, D.I., Wickens H. de V., Christie, A.D.M., Roberts, D.L and Brandl, G., Sedimentary Rocks of the Karoo Supergroup. In: Johnson, M.R., Anhaeusser, C.R. and Thomas, R.L. (Eds.), The Geology of South Africa. Geological Society of South Africa, Johannesberg/Council for Geoscience, Pretoria. p 461-499. 2006

[16] Visser, J.N.J. Post-glacial Permian stratigraphy and geography of southern and central Africa: boundary conditions for climatic modelling. Palaeogeog., Palaeoclimatol., Palaeocol. 118, 213243. 1995

[17] Catuneanu, O., Hancox, P. J. and Rubidge, B.S.,. Reciprocal flexural behaviour and contrasting stratigraphies: a new basin development model for the Karoo retroarc foreland system, South Africa. Basin Research, vol. 10, p 417-439.1998

[18] Bamford, M.K. Diversity of woody vegetation of Gondwanan southern Africa. Gondwana Research 7, 153-164. 2004

[19] Duncan, A.R. \& Marsh, J.S. The Karoo Igneous Province. In: Johnson, M.R., Anhaeusser, C.R. \& Thomas, R.J. (Eds.). 2006. The geology of South Africa, pp. 501-520. Geological Society of South Africa, Marshalltown

[20] Loke, M. H. Tutorial: 2-D and 3-D Electrical Imaging Surveys. 2004. 2004 Revised Edition. www.geomom.com

[21] Loke, M.H. Rapid 2D Resistivity and IP Inversion using the LeastSquares Method. 1999. Advanced Geosciences, Inc.: Austin, TX. pp 121. 1999

[22] Pastor, J and Hernández, A.J. Heavy Metals, Salts and Organic Residues in Old Solid Surface Waters in Their Discharge Areas: Determinants for Restoring Their Impact. .2012. Journal of Environmental Management, Vol. 98, 2012, pp. S42-S49

[23] Ahel, M., Mikac, N., Cosovic, B. E. The Impact of Contamination from a Municipal Solid Waste Landfill (Zagreb, Croatia) on Underlying Soil," Water Science and Technology, 1998. Vol. 37, No. 8

[24] World Health Organization (WHO). Guideline for Drinking Water Quality. 1997. 2nd edition Volume 2, Health criteria and other supporting information, World Health Organization, Geneva, pp 9. 1997 